\title{
Partisan power, economic coordination and variations in vocational training systems in Europe
}

\section{Marius R Busemeyer}

Universität Konstanz, Germany

\section{Raphaela Schlicht-Schmälzle}

Universität Konstanz, Germany

\begin{abstract}
This article explores the variation of vocational education and training systems in European countries. From a survey of experts in 15 European countries, we develop a typology along two dimensions: employer involvement and public commitment. In a second step, we explain the variety of skill formation systems, highlighting the importance of partisan power and economic coordination. The causal argument is applied in three illustrative case studies of Germany, Sweden and the UK. In particular, we argue that a high degree of economic coordination increases the relevance of training relative to academic education. However, differences within the cluster of coordinated market economies are related to different legacies of partisan power in the post-war decades.
\end{abstract}

\section{Keywords}

Economic coordination, Germany, partisan power, Sweden, UK, varieties of capitalism, vocational training

\section{Introduction}

The central aim of this article is to explain the large variations in vocational education and training (VET) systems in Western Europe. In contrast to other sectors of the education system such as higher education, the governance structure of VET systems is much less studied from an international comparative perspective. Early attempts to group and

\footnotetext{
Corresponding author:

Marius R Busemeyer, Universität Konstanz, PO Box 79, Konstanz 78457, Germany.

Email: marius.busemeyer@uni-konstanz.de
} 
classify training systems (Blossfeld, 1992; Crouch et al., 1999; Greinert, 1995; Lynch, 1994 ) identified three ideal-typical models of governance, depending on whether the state, markets or corporatist associations play the leading part in VET provision and financing. However, these early contributions were largely based on the study of individual country cases and did not provide a quantitative measure of differences across countries. Furthermore, the literature so far has spent more energy on describing the differences in training systems than on explaining where these differences come from.

This article aims to fill these gaps. First, on the basis of a large expert survey, we derive quantitative indicators of the degree of employer involvement in and public commitment to VET: two dimensions of variation that have been found useful in order to describe the variation of training regimes in OECD countries (Anderson and Hassel, 2007; Busemeyer, 2009a; Busemeyer and Trampusch, 2012). In this, we move significantly beyond the state of the art in the literature by providing a metric to place countries in a macro-level comparative context. Second, we do not only describe differences, but try to explain them by combining existing theories of public policy-making in a novel way. More specifically, the 'varieties of capitalism' $(\mathrm{VOC})$ literature highlights the importance of non-market coordination among firms for the establishment and long-term survival of VET systems (Estévez-Abe et al., 2001; Hall and Soskice, 2001; Thelen, 2004). More recent work in this field explores the interplay between economic coordination and labour market institutions on the one hand and party politics on the other (Cioffi and Höpner, 2006; Cusack et al., 2007; Deeg and Jackson, 2006; Iversen and Soskice, 2006; Martin and Swank, 2008, 2011; Martin and Thelen, 2007). More specifically with regard to education and training policies, Iversen and Stephens (2008) have shown how different 'worlds of human capital formation' are linked to different varieties of capitalism. They highlight the important distinction between the Continental European variety of coordinated capitalism, associated with conservative-corporatist education and training systems, and the Scandinavian variety, linked to the universalist Nordic model of education. The present article continues this line of work by providing new empirical data as well as a more focused theoretical explanation for the joint impact of employer coordination and partisan politics on VET institutions, backed up by three explorative case studies of the evolution of training policies in Germany, Sweden and the UK.

\section{Employer involvement in and public commitment to VET}

Previous research identifies two dimensions that help map the diversity of VET systems: employer involvement in and public commitment to VET (Busemeyer, 2009a; Busemeyer and Trampusch, 2012; Martin, 2012). ${ }^{1}$ The first indicates whether employers (or their associations) are involved in initial VET through apprenticeship training schemes, whether they help determine the curriculum or whether they decide autonomously about the hiring of apprentices. The second reflects the degree of state involvement in the provision and financing of VET (either in schools or apprenticeship training), the institutional character of secondary education (whether it has distinct vocational training tracks or not) and the certification of vocational skills.

We distinguish four ideal types of skill regimes (Table 1), representing combinations of high and low values on our two dimensions. Empirical cases, as we will see below, 
Table I. Mapping the diversity of VET systems.

\begin{tabular}{lll}
\hline & Weak employer involvement & Strong employer involvement \\
\hline Strong public commitment & Statist system & Collective system \\
Weak public commitment & Residual system & Employer-dominated system \\
\hline
\end{tabular}

always represent a hybrid mix of different ideal types. First, we define statist systems, in which VET is integrated into the secondary school system and students can easily change from the vocational track to higher education, while employer involvement is marginal.

Second, we identify collective skill formation systems, in which intermediary organizations such as employers' associations, but also trade unions and works councils, play a crucial role in the governance of VET (Hilbert et al,, 1990; Streeck et al., 1987), and employers have a large influence on the content of training. State actors are also involved in running the system, but their role is of a different nature than in statist systems; rather than providing VET themselves, state actors play the role of moderators (Hilbert et al., 1990: 52) and delegate obligations and competencies to 'private interest governments' (Streeck and Schmitter, 1985).

The third ideal type, employer-dominated (or segmentalist) systems (Busemeyer, 2009a; Busemeyer and Trampusch, 2012), delegates more decision-making autonomy to individual employers. Associations and state actors are less involved in designing the content of training, and individual firms can decide more freely. In international comparisons, Japan is usually cited as the representative of this type of skill system (Thelen, 2004).

The fourth ideal type has both low public commitment and little employer involvement. In previous research, this type was called the liberal skill regime (Busemeyer and Trampusch, 2012), but in the present context, we prefer to call it the residual type, because in the VoC literature the notion of a liberal regime corresponds to the concept of a general skill system with a focus on academic education. However, some countries (as in Southern Europe) lack commitment to VET but have no extensive higher education sector either.

\section{Measuring diversity: Evidence from an expert survey}

Collecting high-quality comparative data on education systems is notoriously difficult (Heidenheimer, 1996). Since the mid-1990s, the OECD has developed a database on all aspects of education systems, such as levels of public and private spending, patterns of enrolment, rates of return to human capital investments and educational output. However, this collection provides few data on the diversity of vocational education and training systems. One reason is that VET systems are inherently more complex and more varied in their governance structure than other sectors of the education system. The database does provide some data on patterns in upper secondary school enrolment (OECD, 2010: 305 ), and similar data on the share of students in technical and vocational education at secondary level are available from UNESCO. These are commonly used in the VoC literature to measure the incidence of vocational training or 'skill specificity' at the macrolevel (Cusack et al., 2006; Estévez-Abe et al., 2001; Iversen and Soskice, 2001). 
Unfortunately, this involves several problems. The UNESCO data do not distinguish between school- and workplace-based VET systems. Hence countries with extensive school-based VET, such as Sweden and France, are grouped with dual system countries such as Germany or Austria (Iversen and Soskice, 2001: 888), neglecting differences in the underlying political economy. Recent OECD data are an improvement, because they contain information on the share of students in combined school- and workplace-based training schemes (apprenticeships). However, this indicator has many missing values because of the inherent difficulties of comparison. Furthermore, the OECD data do not distinguish between different degrees of employer involvement in the governance of VET systems. A final problem is that initial VET is sometimes treated as uppersecondary, sometimes as post-secondary or even as lower-secondary education, which leads to misclassifications and biases.

In short, the OECD data are not sufficiently fine-grained, do not take into account qualitative differences in the institutional structure of VET systems and omit many countries. As an alternative, we conducted an expert survey on VET systems: an approach with both advantages and disadvantages. The crucial advantage is that it is possible to obtain more fine-grained data on the institutional characteristics of training systems. A potential disadvantage is that concepts such as apprenticeship training might be understood differently in different countries. We tried to mitigate this problem in the design of the questionnaire by providing exact definitions of our terms and concepts. Another problem is that the number of experts for some counties might be low; because we were interested in the specific issue of governance arrangements, this limited the size of our pool of potential experts.

As a first step, we identified a number of VET experts - both academics and practitioners - through internet searches, a reading of scholarly publications and academic networks. Of course, this is not a random sample, but the goal was to recruit as many experts as possible per country case. Our initial sample included 193 experts in 23 OECD member states, who were contacted by both regular and electronic mail. A number of experts were asked to fill out the online questionnaire for more than one country if appropriate. The survey ran from April to October 2011. For almost all countries, we have more than one response; but for Finland, and France we had only a single expert opinion, although we asked a large number of experts to contribute.

We ended up with 90 completed questionnaires. In the next step, we excluded those cases in which more than five questions contained missing values, to ensure that the experts were indeed well informed. It is possible that the institutional characteristics of some VET systems might have made it more difficult to answer our questions. In order to ensure the comparability of responses, we decided to restrict our final sample to Western Europe only. This resulted in 54 completed questionnaires for 15 countries: Austria, Belgium, Denmark, Finland, France, Germany, Greece, Ireland, Italy, Luxembourg, Netherlands, Norway, Sweden, Switzerland and the UK. Further information on the survey, additional results for more countries as well as the codebook and questionnaire are available online.

The questionnaire included 20 questions on employer involvement (covered by 10 questions) in and public commitment to VET (13 questions); some questions were relevant for both. The answers were coded between 0 (weak employer involvement or weak 
public commitment) and 1 (strong employer involvement or strong public commitment) with intermediate categories where appropriate. For each case (a case is one questionnaire by a single expert for a single country), an additive index was calculated for each dimension. Some of the questions were weighted twice since their relevance for one of the two dimensions is higher than for the other. For example, questions pertaining to the general popularity or relevance of VET in upper secondary education were weighted twice, while more detailed questions on the organization of school based training, the role of public subsidies or the organization of apprenticeships are only weighted once. ${ }^{2}$

Finally, the aggregated indices for employer involvement and public commitment were calculated by taking the mean for each country. The number of questionnaires included in this procedure varies by country, from nine for Germany to only one for Finland and France.

However, one further step is required. As we are interested in the degree of public commitment and employer involvement in VET for the political economy as a whole, we need to take into account the extensiveness of the VET system. There is a great difference between a country in which both employers and the state are committed to initial VET, but few students participate (as in Ireland), and one with high levels of commitment from the state and employers as well as high participation (Germany). Therefore, we multiply our indices by indicators of the extensiveness of the VET sector. In particular, the dimension of public commitment is weighted by the share of upper-secondary pupils in vocational education (school-based plus workplace-based), for which the OECD provides reasonably good data. The index of employer involvement is multiplied by a qualitative indicator that measures the actual relevance of apprenticeships in these countries and is partly based on the OECD data mentioned above. Values for countries with a low share of upper secondary students in apprenticeship training $(0-5 \%)$ are multiplied by 0.33 (Italy, Greece, Spain, Belgium and Ireland). Values for countries with moderate share (5-30\%) are multiplied by 0.66 (France, Finland, Luxembourg, Norway, UK and Netherlands). Values for countries with high share are multiplied by 1 (Austria, Denmark, Germany and Switzerland). The absolute values of the qualitative indicator do not matter as the final index used in the analysis is standardized by $\mathrm{z}$ transformation, that is, standardized to a mean of zero and a standard deviation of 1 (Table 2). By doing this, we engage in an analysis of the VET systems given the relevance of vocational education in a country. Hence, public commitment and firm involvement are not considered strong in countries with less extensive VET systems and low enrolment rates in apprenticeships.

Table 2. Standardized weighted index values: employer involvement (EI) and public commitment (PC).

\begin{tabular}{|c|c|c|c|c|c|c|c|c|}
\hline & AT & $\mathrm{BE}$ & $\mathrm{CH}$ & $\mathrm{DE}$ & DK & $\mathrm{FI}$ & FR & GR \\
\hline El & 1.23 & -0.97 & 1.66 & 1.65 & 1.68 & -0.24 & -0.16 & -1.09 \\
\hline \multirow[t]{2}{*}{$\mathrm{PC}$} & 0.81 & 1.51 & -0.14 & 0.13 & -0.13 & 0.23 & 0.43 & -0.58 \\
\hline & IE & IT & LU & $\mathrm{NL}$ & NO & SE & UK & \\
\hline $\mathrm{El}$ & -0.97 & -0.92 & 0.36 & -0.22 & 0.13 & -1.03 & -0.16 & \\
\hline $\mathrm{PC}$ & -1.86 & -1.10 & 0.56 & 1.86 & 0.09 & 0.57 & -0.63 & \\
\hline
\end{tabular}




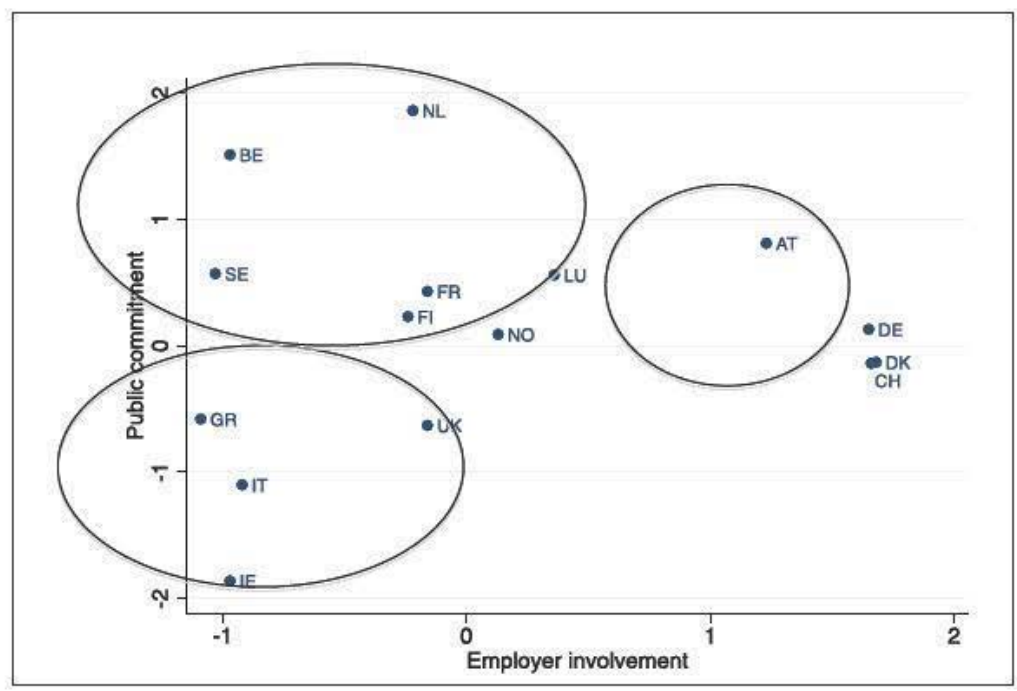

Figure I. Matrix of employer involvement and public commitment.

In our sample, the Netherlands provides the highest public commitment to VET and Ireland the lowest. With employer involvement, Denmark, Germany, and Switzerland exhibit the highest values and Greece the lowest.

Figure 1 shows the distribution of countries across the four possible skill formation types. Belgium, Finland, France, Netherlands, Norway and Sweden are allocated to the statist category: public commitment to VET is strong, while employer involvement is weak. Greece, Ireland, Italy and United Kingdom belong to the residual type with weak public commitment and weak employer involvement. This cluster is heterogeneous in terms of post-secondary education systems; our two dimensions only capture specific aspects of the initial VET system, but neglect other characteristics of post-secondary education, primarily higher education. In Ireland and the UK, the lack of public commitment to VET may be compensated by well-established tertiary education systems. In contrast, Italy and Greece combine a weak VET system with weakly developed tertiary education.

Austria, Germany, Denmark and Switzerland represent the collective type: we find strong employer involvement in VET and medium-strong public commitment (Busemeyer and Trampusch, 2012). Switzerland and Denmark are closest to the employer-dominated skill formation system. In the former there is a weaker degree of public commitment to VET, which may be related to the weaker role of unions in the governance structure; in the latter, there are lower levels of public commitment than in the other Scandinavian countries, because workplace-based training is more important here (Nelson, 2012). There are no examples of employer-dominated systems in our sample of European countries.

The circles in Figure 1 indicate that country cases largely group into three recognizable clusters, which is consistent with more elaborate cluster analyses of education regimes (Iversen and Stephens, 2008; West and Nikolai, 2013). Below, we look in greater 
detail at the cases of Germany, Sweden and the UK as representative cases for each of the clusters.

\section{Political and institutional determinants of variation in VET systems}

Having been concerned with measuring and describing the variety of VET systems, we now ask how we can explain this variety. Which political and institutional factors pushed VET systems onto different development paths in the past, resulting in today's institutional diversity? Here, we focus on the two factors that are most intensely discussed in the literature: the degree of economic coordination or varieties of capitalism (Hall and Soskice, 2001); and differences in the historical balance of power between political parties in government. However, our main hypothesis is that these factors matter in combination; examining the impact of partisan politics or economic coordination alone is insufficient. We must take into account the interaction between politics and economic coordination, as is also increasingly recognized in the literature (Cioffi and Höpner, 2006; Cusack et al., 2007; Iversen and Stephens, 2008; Martin and Swank, 2008, 2011).

\section{The degree of coordination}

The VoC literature identified VET regimes as crucial institutional elements of coordinated market economies (CMEs) (Hall and Soskice, 2001: 25-26): differences in the degree and kind of economic coordination are believed to be related to different skill regimes. In CMEs, where firms rely on non-market forms of coordination, investments in vocational skills are supported by a dense network of socio-economic institutions, such as collective wage bargaining, cooperative relationships between business and labour, corporate governance institutions favouring long-term human capital investment strategies and strong employers ${ }^{2}$ associations. Non-market coordination allows firms to solve problems of market failure in the joint production of human capital (Finegold and Soskice, 1988), which leads to a higher willingness of employers to provide training. Employment and social protection in turn enhance the willingness of workers to invest in vocational skills (Estévez-Abe et al., 2001). In countries where high-quality vocational skills are widely available, firms develop a competitive advantage in 'diversified quality production' (Streeck, 1992) of high-quality manufacturing goods. These economic benefits contribute to the long-term political sustainability of collective skill systems, although they might impose short-term costs on firms (Busemeyer and Trampusch, 2012; Streeck, 1992).

In contrast, liberal market economies (LMEs) emphasize academic skills, usually acquired within the formal higher education system and complemented by a web of socio-economic institutions enforcing coordination through market mechanisms. Where non-market forms of coordination are not available, firms rely on the general skills provided in the higher education sector, which in turn is associated with a comparative advantage in product markets relying on radical rather than incremental innovation (software, biotechnology, pharmaceuticals). The lack of stable coordination mechanisms among employers aggravates the problem of poaching: firms are reluctant to invest in 
employee skills that are potentially transferable, resulting in a limited involvement in skill provision beyond the immediate firm context (Busemeyer, 2009a).

The bottom line for this literature is that socio-economic institutions create incentives for firms as well as young people to invest in different kinds of skills. When non-market coordination is high, we would expect stronger reliance by both the state and employers on vocational skills. In contrast, when coordination is low, we expect weak reliance on vocational education. Hence the VoC literature draws a broad distinction between LMEs with a focus on academic education and CMEs with an emphasis on vocational education. However, it is possible to differentiate further between types of labour market coordination within the large group of CMEs (Estévez-Abe et al., 2001; Hicks and Kenworthy, 1998; Martin and Thelen, 2007). For example, a high degree of firm-level corporatism could be associated with employer-dominated skill regimes. In contrast, strong corporatism at the meso- or macro-level should be associated with a stronger involvement of employers in more collective forms of skill provision. We argue that differences within the group of CMEs are broadly related to different legacies of partisan power.

\section{Legacies of partisan power}

A large (and growing) literature suggests that the partisan composition of governments is strongly associated with patterns of public and private spending on education (Ansell, 2010; Boix, 1997; Busemeyer, 2007; Iversen and Stephens, 2008; Schmidt, 2007). A robust finding is that the government participation of leftist (social-democratic) parties is associated with increased public investments in education in general. Therefore, our hypothesis is that social democrats in government (supported by strong unions) were more reluctant to involve employers in initial VET, fearing that they might employ apprentices as cheap substitutes for skilled workers. Still, social democrats did care more about expanding types of education that are more relevant for their main electoral constituencies. This is particular true for the post-war decades when VET was still the primary route of education for a majority of young people in most countries. Hence we expect a positive association between public commitment to VET and the historical strength of the left.

This also implies the counter-argument: countries with a strong partisan heritage of liberal-conservative parties should exhibit lower levels of public commitment to VET, for two reasons. First, conservative parties tend to concentrate public investment on higher education or private education (Ansell, 2010; Wolf, 2009). Second, they are less likely to support non-market based forms of economic coordination, which are a necessary condition for the establishment of extensive VET systems.

There is however an important difference between secular conservatives and Christian democrats. The comparative welfare state literature identifies Christian democracy as a third partisan ideology with distinctive implications for welfare state development (Esping-Andersen, 1990; Huber and Stephens, 2001; Iversen and Stephens, 2008; van Kersbergen, 1995). In contrast to secular conservatism, Christian-democratic ideology, rooted in social Catholicism, expresses a stronger concern for the social compensation of negative side-effects of markets. However, there are also important differences between social-democratic and Christian-democratic ideology. Whereas social democrats are 
strongly in favour of statist solutions, Christian democrats embrace the principle of subsidiarity. This means that civil society organizations (in former times: the churches and associated welfare associations) should be responsible for providing social services and education to the largest extent possible, and the state should only step in when absolutely necessary. Christian-democratic ideology is deeply committed to 'settlement between possibly opposed social interests' (van Kersbergen, 1995: 1), mediating cross-class conflict, which distinguishes it from both social democracy and secular conservatism.

These insights from the welfare state literature can also be applied to vocational training. First, we would expect Christian democracy to be associated with a particular type of state involvement in VET. Instead of direct involvement in providing and financing VET, it limits the role of the state to that of a mediator and promoter of cross-class compromise, establishing and maintaining a supportive institutional infrastructure, such as corporatist chambers of commerce. The training of young people is thus delegated to 'private interest governments' (Streeck and Schmitter, 1985), involving employers and their associations. However, in contrast to market-friendly conservatism, employers are expected to play their role by providing sufficient training opportunities for young people and accepting unions as part of encompassing cross-class coalitions. Thus, Christiandemocratic ideology promotes employer organization and also depends on it in order to stimulate employer involvement in skill formation. In the statist VET system, a high degree of economic coordination supports the establishment of cross-class coalitions promoting vocational education compared to academic education (Cusack et al., 2007; Martin, 2012), but the predominance of social democracy and strong unions leads to a strong preference for statist solutions, crowding out employers in the provision of training. Finally, in liberal skill systems, the lack of coordination inhibits attempts by political parties to stimulate collective forms of skill formation (Finegold and Soskice, 1988), although historically, the British Labour party had repeatedly tried to do so.

In sum, partisan power and macroeconomic coordination have to be regarded jointly, if only because partisan politics also has an effect on economic coordination - as Iversen and Stephens (2008) argue. This hypothesis will be explored in the following illustrative case studies of Germany, Sweden and the UK. Here, we adopt an analytical perspective rooted in historical institutionalism (Pierson, 2004; Thelen, 2004). This approach emphasizes the importance of path dependency and the sequencing of historical events: events that happen at an earlier point in time are of greater relevance for the formation of development paths than later events. Therefore, the focus of the following case studies will be on the critical junctures of path formation in each country. These were the 1960 s and 1970 s in Germany and Sweden, and the 1980s in the UK.

\section{Illustrative case studies}

\section{Germany}

The roots of coordinated capitalism and firm-based training in Germany go back to the late 19th century (Greinert, 1998; Thelen, 2004). Before the 1969 Berufsbildungsgesetz (Federal Law on Vocational Education and Training, BBiG), apprenticeship training remained a matter of self-government in the hands of employers, in particular the 
semi-public chambers (Industrie- und Handelskammern and Handwerkskammern). The ability and willingness of employers to rely on non-market forms of coordination through the chambers and strong employers' associations prevented the poaching of skilled workers and encouraged them to invest in skill formation. After the Second World War, the rising power and influence of trade unions represented a challenge to this employerdominated system. Unions had lobbied for a comprehensive legislative framework since the days of the Weimar Republic, because they feared that employer dominance in the system could lead to the abuse of apprentices as cheap labour. The social democrats (Sozialdemokratische Partei Deutschlands, SPD), who were in opposition until the advent of the first 'grand coalition' in 1966, supported unions in this effort and prodded the government led by the Christian democrats (Christlich-Demokratische Union, CDU) to introduce legislation. This was finally achieved with the passing of the BBiG in 1969 by the CDU-SPD coalition government. This law 'brought greater unity to the previously disparate legal framework ${ }^{2}$ (Thelen, 2004: 262), but the core characteristics of the existing system were maintained. Unions were given a greater say in the chambers, as well as in the process of reforming and updating regulations on the definition and certification of craft occupations. In general, however, unions and the social democrats were disappointed by the limited reach of the law (Kuda and Mignon, 1982).

This is why the transformation of the German VET system from a collective to a more statist variety along Scandinavian lines was one of the most important reform projects of the new government coalition between the SPD and liberals (Freie Demokratische Partei, FDP) that came into power in 1969. As would be expected from the perspective of partisan theory, the SPD wanted to improve educational opportunities for children from lower income classes by expanding access to higher education, but also by integrating VET into the general secondary school system, as happened in Sweden at the same time. This triggered widespread resistance from the employers, who at one point threatened to boycott the apprenticeship training system altogether (Baethge, 1983: 148).

The CDU largely sided with the employers. When they came back to power in 1982 , they immediately scrapped any plans for large-scale reform of the system although because of an increase in the number of school-leavers, there was an acute shortage of training places. Instead of pushing employers by threatening the introduction of a training levy, as the previous government had done, the CDU adopted a typical corporatist approach, in effect appealing to the chambers and employers' associations to step up their efforts (Busemeyer, 2009b: 106-107). In contrast to the Conservatives in the UK, German Christian democrats emphasized the value of VET as compared to academic education (Wilms, 1983) and expected employers to contribute to the maintenance of the dual, firm-based system. In contrast to the social democrats, they opposed statist approaches: instead of integrating VET into the general school system, it should be maintained as a separate, distinct but valuable educational pathway (Wilms, 1983: 86). Furthermore, the CDU recognized unions 'rights to be included in the process of reforming and updating training curricula and certification, as long as this did not lead to the transformation of the system from a collective to a statist variety. 


\section{Sweden}

In Sweden, the political situation was very different; in the Scandinavian countries, Christian-democratic parties do not exist or are very weak. In 1932 the social democrats (Sveriges socialdemokratiska arbetareparti, SAP) came to power in coalition with the agrarian party (the 'red-green' alliance) and was in government almost continuously until 1976. After the historic compromise between employers and trade unions in the Saltsjöbaden Agreement of 1938, social-democratic dominance in the electoral arena coexisted with powerful unions and well-organized employers in the labour market arena. In the 1950s, the SAP started a decades-long process of transforming the education system (Härnqvist, 1989). Initially, Sweden's education system was not very different from the German one, since it also had different tracks in secondary education as well as an elitist higher education system. After an initial process of experimentation, the government established the nine-year comprehensive school (grundskola) as the standard school in 1962; this was widely regarded as an integral component of the universalist social-democratic welfare state (Hudson and Lidström, 2002: 35) and a comerstone of the 'Nordic model of education' (Antikainen, 2006).

After the comprehensive basis of lower secondary education was established, the next step was to overcome the distinction between VET and academic education at the upper secondary level. In former times, the traditional grammar school (Gymnasium) existed alongside and institutionally separated from a range of VET tracks offered in different school settings. In 1969, the government passed a crucial reform (which came into force in 1972) that led to the full integration of VET tracks into the general secondary school system, in order to reduce the differences between VET and academic education (Härnqvist, 1989: 25-26). To promote educational mobility, graduates from the VET track of the newly integrated upper secondary school could immediately proceed to higher tertiary education. This is a crucial difference from the German system, where the permeability between VET and higher education is still very low (Powell and Solga, 2011).

Another crucial difference is that VET is usually provided in school settings, whereas the workplace plays a key role in Germany. Lundahl (1997: 93), however, points out that the number of apprentices in Sweden in 1945 was about as high as the number of students in state-sponsored vocational schools (about 10,000). Thus, the reforms of the 1960 s and the 1970s should be regarded as the real critical juncture that transformed Sweden into a statist rather than a collective skill regime. Later attempts of various governments to increase the involvement of employers in the provision of training, in order to counter the persistently high levels of youth unemployment, largely failed (Lundahl, 1997, 1998).

An important difference between Sweden and the UK, however, is that the status of VET in general and the level of public commitment are much higher. Since Sweden is a prime example of a $\mathrm{CME}$, unions and employers have jointly maintained pressure on governments to improve the linkages between secondary education and the labour market, as well as to maintain VET as a viable alternative to academic education (Lundahl, 1998: 43). 


\section{The UK}

Compared to Germany and Sweden, the partisan balance of power between Labour and the Conservatives in the UK was more even in the post-war decades (because the "firstpast-the-post' electoral system has meant that small differences in popular votes can translate into clear parliamentary majorities). This may help explain why the institutional character of the political economy was more mixed than a pure LME (Hall, 1992). In the realm of VET, the 1964 Industrial Training Act established a relatively collectivist levygrant system, and unions and employers were willing and able to work together on matters of training policy in the post-war phase (Perry, 1976: 49). This consensual approach also prevailed in the field of general education, where the expansion of opportunities at the secondary and tertiary level and the establishment of comprehensive secondary schools was promoted by both Conservative and Labour governments (Ansell, 2010; Chitty, 2004).

Partisan conflict increased during and after the tumultuous 1970s. Until then, apprenticeship training had been an important pathway to skilled employment in the industrial sector. Union efforts to use apprenticeship training to limit the supply of skilled labour eventually contributed to the demise of the collective institutional framework during the 1980s under Thatcher. Here, the critical juncture was the decision of the Conservative government to shift the focus of training policy from skill formation towards the prevention of youth unemployment, in the form of the Youth Training Scheme (YTS), first established in 1982. Although considerable resources were deployed on YTS and its successor programmes, the emphasis was on quantity rather than quality of training. In part, YTS crowded out old-style apprenticeship training programmes. In the late $1980 \mathrm{~s}$, the government changed the governance structure of the system, as part of a more general rejection of tripartism. Old-style training boards (established under the $1964 \mathrm{act}$ ) were abolished (with minor exceptions), the tripartite Manpower Service Commission (MSC) was effectively dismantled and all relevant matters related to training policy were put in the hands of Training and Enterprise Councils (TECs) (King, 1993: 226-227). These were completely dominated by employers; unions and other stakeholders had no statutory right of representation.

Although various governments (such as the Major government in the 1990s) tried subsequently to resuscitate the traditional apprenticeship training system, they largely failed to change the liberal-voluntarist character of the system (King, 1997; Ryan and Unwin, 2001). The reason is the well-known lack of economic coordination among employers (Finegold and Soskice, 1988; Hall and Soskice, 2001), which inhibits serious investment in initial skill formation, because employers face the risk of poaching. Despite efforts to improve the authoritative certification of vocational skills (as with the system of National Vocational Qualifications, introduced in 1986), this voluntarist system allows employers to pursue a 'cafeteria approach' (Ryan and Unwin, 2001: 110) to skill formation, training according to narrowly defined needs instead of broad occupational profiles. Over the long term, this has led to the decline of the status of apprenticeship training and VET in particular, contributing to a shifting focus from VET to higher education among parents, employers and policy-makers. The British Conservatives are less enthusiastic about VET than the German CDU (King, 1993), although they have rediscovered 
apprenticeship training from time to time. More important than this difference in policy preferences may be the different approach to the process of policy-making. Whereas the CDU prefers cross-class compromise and a politics of mediation, Conservatives have engaged in more confrontational strategies of partisan conflict. Finally, even in those cases when governments tried to resuscitate apprenticeship training, the liberal character of the British economy made it highly unlikely that employer involvement could be increased in the long term (Finegold and Soskice, 1988). Compared to other LMEs, in particular the North American varieties, public commitment to VET was higher in the UK, probably because of the policy legacies of apprenticeship training. Hence a potential issue for future research could be to pay more attention to the differences between skill formation in LMEs (following Gospel, 1994).

\section{Conclusion}

This article began by devising a typology of VET systems. We argued that systems vary along two dimensions: public commitment and employer involvement. We then presented data on these two dimensions, devised from a large expert survey. We thereby identified three empirically relevant ideal types: the statist, collective and liberal or residual systems. We then endeavoured to explain the position of countries on these two dimensions, arguing both partisan politics and economic coordination are centrally relevant for the explanation of different development paths. The causal argument was applied in three illustrative cases of the post-war history of VET policy-making in Germany, Sweden and the UK. Clearly, these 'proto-case studies' are only a first step, and a more detailed analysis of historical developments should be addressed in future research (Busemeyer, forthcoming).

The core insight of this article for a general readership is that more attention should be paid to the interaction of partisan politics and systems of industrial relations. The policy options from which policy-makers can choose might vary in different varieties of capitalism. For example, moving back from a liberal to a collective skill formation system will probably be impossible in the UK. In CMEs, the joint efforts of unions and employers have kept VET alive as an alternative to higher education. However, varieties of capitalism do not determine policy choices. The variety of skill formation regimes within the clusters of LMEs and CMEs can, at least in part, be explained by different partisan legacies. The Swedish approach of integrating VET into the secondary school system can hardly be understood without reference to the project of establishing a 'Nordic model of education' (Antikainen, 2006) as part of a universal welfare state. The German emphasis on maintaining VET as a separate, but cherished alternative to academic education relates to the distinctive approach of Christian democrats to education and social policy (van Kersbergen, 1995).

\section{Funding}

Research for this project was partly funded by a grant from the German Research Foundation (DFG), no. BU 1852/4-1. 


\section{Notes}

1. Blossfeld (1992) adds a third dimension: stratification. In our view, this would better be treated as an outcome variable, reflecting the effect of institutions on the labour market.

2. See list of weighted questions in the online codebook, available at http:/www.polver.unikonstanz.de/en/busemeyer/emmy-noether-project/publications/. Here, we also provide more detailed reasons for the weighting procedure. Questionnaires that contained missing values for the weighted questions have also been excluded from the analyses. One questionnaire with missing values on weighted question was not excluded for the dimension employer involvement, since the missing responses applied only to the public commitment dimension.

\section{References}

Anderson KM and Hassel A (2007) Pathways of change in CMEs: Training regimes in Germany and the Netherlands. Paper to the American Political Science Association Meeting, Chicago, IL, September.

Ansell BW (2010) From the Ballot to the Blackboard: The Redistributive Political Economy of Education. Cambridge: Cambridge University Press.

Antikainen A (2006) In search of the nordic model in education. Scandinavian Journal of Educational Research 50(3): 229-243.

Baethge M (1983) Berufsbildungspolitik in den siebziger Jahren: Eine Lektion in ökonomischer Macht und politischer Ohnmacht. In: Lipsmeier A (ed.) Berufsbildungspolitik in den 70er Jahren: Eine kritische Bestandsaufnahme für die 80er Jahre. Wiesbaden: Franz Steiner Verlag, pp. 145-157.

Blossfeld H-P (1992) Is the German dual system a model for a modern vocational training system? International Joumal of Comparative Sociology 33: 168-181.

Boix C (1997) Political parties and the supply side of the economy: The provision of physical and human capital in advanced economies, 1960-1990. American Joumal of Political Science 41: 814-845.

Busemeyer MR (2007) The determinants of public education spending in 21 OECD democracies, 1980-2001. Journal of European Public Policy 14: 582-610.

Busemeyer MR (2009a) Asset specificity, institutional complementarities and the variety of skill regimes in coordinated market economies. Socio-Economic Review 7: 375-406.

Busemeyer MR (2009b) Wandel trotz Reformstau: Die Politik der beruflichen Bildung seit 1970. Frankfurt: Campus.

Busemeyer MR and Trampusch C (2012) Introduction: The comparative political economy of collective skill formation. In: Busemeyer MR and Trampusch C (eds) The Political Economy of Collective Skill Formation. Oxford: Oxford University Press, pp. 3-38.

Busemeyer MR (forthcoming) Skills and Inequality: The Political Economy of Education and Training Reforms in Western Europe. Cambridge: Cambridge University Press.

Chitty C (2004) Education Policy in Britain. Basingstoke: Palgrave Macmillan.

Cioffi JW and Höpner M (2006) The political paradox of finance capitalism: Interests, preferences, and center-left party politics in corporate governance reform. Politics and Society 34: 463-502.

Crouch C, Finegold D and Sako M (1999) Are Skills the Answer? The Political Economy of Skill Creation in Advanced Industrial Countries. Oxford: Oxford University Press.

Cusack T, Iversen T and Rehm P (2006) Risks at work: The demand and supply sides of government redistribution. Oxford Review of Economic Policy 22: 365-389. 
Cusack T, Iversen T and Soskice D (2007) Economic interests and the origins of electoral systems. American Political Science Review 101: 373-391.

Deeg R and Jackson G (2006) How many varieties of capitalism? Comparing the comparative institutional analyses of capitalist diversity. MPIfG Discussion Paper 06.

Esping-Andersen G (1990) The Three Worlds of Welfare Capitalism. Cambridge: Polity Press.

Estévez-Abe M, Iversen T and Soskice D (2001) Social protection and the formation of skills: A reinterpretation of the welfare state. In: Hall PA and Soskice D (eds) Varieties of Capitalism: The Institutional Foundations of Comparative Advantage. Oxford: Oxford University Press, pp. 145-183.

Finegold D and Soskice D (1988) The failure of training in Britain: Analysis and prescription. Oxford Review of Economic Policy 4: 21-53.

Gospel HF (1994) The survival of apprenticeship training: A British, American, Australian comparison. British Joumal of Industrial Relations 32(4): 505-522.

Greinert W-D (1995) Regelungsmuster der beruflichen Bildung: Tradition, Markt, Bürokratie. BWP 24/1995: 31-35.

Greinert W-D (1998) Das 'deutsche System' der Berufsausbildung: Tradition, Organisation, Funktion. Baden-Baden: Nomos.

Hall PA (1992) The movement from Keynesianism to monetarism: Institutional analysis and British economic policy in the 1970s. In: Steinmo S, Thelen K and Longstreth F (eds) Structuring Politics: Historical Institutionalism in Comparative Perspective. Cambridge: Cambridge University Press, pp. 90-113.

Hall PA and Soskice D (2001) An introduction to varieties of capitalism. In: Hall PA and Soskice $\mathrm{D}$ (eds) Varieties of Capitalism: The Institutional Foundations of Comparative Advantage. Oxford: Oxford University Press, pp. 1-68.

Hämqvist K (1989) Comprehensiveness and social equality. In: Ball SJ and Laesson S (eds) The Struggle for Democratic Education: Equality and Participation in Sweden. London: Falmer Press, pp. 18-31.

Heidenheimer AJ (1996) Throwing money and heaving bodies: Heuristic callisthenics for comparative policy buffs. In: Imbeau LM and McKinlay RD (eds) Comparing Government Activity. Basingstoke: Macmillan, pp. 13-25.

Hicks A and Kenworthy L (1998) Cooperation and political economic performance in affluent democratic capitalism. American Joumal of Sociology 103: 1631-1672.

Hilbert J, Südmersen H and Weber H (1990) Berufsbildungspolitik: Geschichte, Organisation, Neuordnung. Opladen: Leske + Budrich.

Huber E and Stephens JD (2001) Development and Crisis of the Welfare State: Parties and Policies in Global Markets. Chicago, IL: University of Chicago Press.

Hudson C and Lidström A (2002) National school policy changes in Britain and Sweden. In: Hudson C and Lidström A (eds) Local Education Policies: Comparing Sweden and Britain. Basingstoke: Palgrave, pp. 27-64.

Iversen T and Soskice D (2001) An asset theory of social policy preferences. American Political Science Review 95: 875-893.

Iversen T and Soskice D (2006) Electoral institutions and the politics of coalitions: Why some democracies redistribute more than others. American Political Science Review 100: $165-181$.

Iversen T and Stephens JD (2008) Partisan politics, the welfare state, and three worlds of human capital formation. Comparative Political Studies 41: 600-637.

King D (1993) The conservatives and training policy 1979-1992: From a tripartite to a neoliberal regime. Political Studies 41(2): 214-235. 
King D (1997) Employers, training policy, and the tenacity of voluntarism in Britain. Twentieth Century British History 8(3): 383-411.

Kuda E and Mignon U (1982) Berufliche Bildung: Situation Konflikte Lösungen. Cologne: BundVerlag.

Lundahl L (1997) A common denominator? Swedish employers, trade unions and vocational education. International Journal of Training and Development 1(2): 91-103.

Lundahl L (1998) Still the stepchild of Swedish educational politics? Vocational education and training in Sweden in the 1990s. In: Lundahl L and Sander T (eds) Vocational Education and Training in Germany and Sweden: Strategies of Control and Movements of Resistance and Opposition. Umea: TNTEE Editorial Office, pp. 39-53.

Lynch LM (1994) Payoffs to alternative training strategies at work. In: Freeman RB (eds) Working under Different Rules. New York: Russell Sage Foundation, pp. 63-95.

Martin CJ (2012) Political institutions and the origins of collective skill formation systems. In: Busemeyer MR and Trampusch C (eds) The Political Economy of Collective Skill Formation. Oxford and New York: Oxford University Press, pp. 41-67.

Martin CJ and Swank D (2008) The political origins of coordinated capitalism: Business organizations, party systems and state structure in the age of innocence. American Political Science Review 102: 181-198.

Martin CJ and Swank D (2011) Gonna party like it's 1899: Party systems and the origins of varieties of coordination. World Politics 63: 78-114.

Martin CJ and Thelen K (2007) The state and coordinated capitalism: Contributions of the public sector to social solidarity in postindustrial societies. World Politics $60: 1-36$.

Nelson M (2012) Continued collectivism: The role of trade self-management and the Social Democratic Party in Danish vocational education and training. In: Busemeyer MR and Trampusch C (eds) The Political Economy of Collective Skill Formation. Oxford: Oxford University Press, pp. 179-202.

OECD (2010) Education at a Glance 2010: OECD Indicators. Paris: OECD.

Perry PJC (1976) The Evolution of British Manpower Policy from the Statute of Artificers 1563 to the Industrial Training Act 1964. London: British Association for Commercial and Industrial Education.

Pierson P (2004) Politics in Time: History, Institutions and Social Analysis. Princeton, NJ and Oxford: Princeton University Press.

Powell JJW and Solga H (2011) Why are higher education participation rates in Germany so low? Institutional barriers to higher education expansion. Journal of Education and Work 24(1-2): $49-68$.

Ryan P and Unwin L (2001) Apprenticeship in the British 'training market'. National Institute Economic Review 178 (October): 99-114.

Schmidt MG (2007) Testing the retrenchment hypothesis: educational spending, 1960-2002. In: Castles FG (eds) The Disappearing State? Retrenchment Realities in an Age of Globalisation. Cheltenham: Edward Elgar, pp. 159-183.

Streeck W (1992) On the institutional conditions of diversified quality production. In: Streeck W and Matzner E (eds) Beyond Keynesianism: The Socio-Economics of Production and Full Employment. Aldershot: Edward Elgar, pp. 21-61.

Streeck W and Schmitter PC (1985) Community, market, state - and associations? The prospective contribution of interest governance to social order. In: Streek W and Schmitter PC (eds) Private Interest Government: Beyond Market and State. London: SAGE, pp. 1-29.

Streeck W, Hilbert J, Van Kevelaer K-H, Maier F and Weber H (1987) Steuerung und Regulierung der beruflichen Bildung: Die Rolle der Sozialpartner in der Ausbildung und beruflichen Weiterbildung in der Bundesrepublik Deutschland. Berlin: edition sigma. 
Thelen K (2004) How Institutions Evolve: The Political Economy of Skills in Germany, Britain, the United States and Japan. Cambridge: Cambridge University Press.

van Kersbergen K (1995) Social Capitalism: A Study of Christion Democracy and the Welfare State. London: Routledge.

West A and Nikolai R (2013) Welfare regimes and education regimes: Equality of opportunity and expenditure in the EU (and US). Journal of Social Policy 42(3): 469-493.

Wilms D (1983) CDU-Berufsbildungspolitik - Erbe und Perspektiven. In: Lipsmeiser A (eds) Berufsbildungspolitik in den 70er Jahren: Eine kritische Bestandsaufnahme für die 80er Jahre. Wiesbaden: Franz Steiner Verlag, pp. 59-68.

Wolf F (2009) The division of labour in education funding: A cross-national comparison of public and private education expenditure in 28 OECD countries. Acta Politica 44(1): 50-73.

\section{Author biographies}

Marius R Busemeyer is Professor of Political Science at the University of Konstanz, Germany.

Raphaela Schlicht-Schmälzle was post-doctoral researcher at the University of Konstanz, Germany. 